Magna Scientia Advanced Research and Reviews

eISSN: 2582-9394

Cross Ref DOI: $10.30574 / \mathrm{msarr}$

Journal homepage: https://magnascientiapub.com/journals/msarr/

(RESEARCH ARTICLE)

\title{
Pharmacognostic evaluation and coagulant analysis of the ethanol extracts of the leaves of Ocimum gratissimum L. (Lamiaceae)
}

Felix N Osuala ${ }^{1,{ }^{*}}$, Maureen C Umewenike ${ }^{1}$ and Philie PE Mounmbegna ${ }^{2}$

${ }^{1}$ Department of Pharmacognosy, Faculty of Pharmacy, Madonna University, Nigeria.

${ }^{2}$ Department of Microbiology, Faculty of Basic Sciences, Madonna University. Nigeria.

Magna Scientia Advanced Research and Reviews, 2022, 04(01), 004-019

Publication history: Received on 15 December 2021; revised on 13 January 2022; accepted on 15 January 2022

Article DOI: https://doi.org/10.30574/msarr.2022.4.1.0085

\begin{abstract}
Ocimum gratissimum belongs to the group of plants known as spices. The plant is an erect small plumb with many branches usually not more than $1 \mathrm{~m}$ high. It is of the familylabiatae, genus Ocimum and species gratissimum. It is commonly known as scent leaf. This project is focused on the pharmacognostic and coagulant activities of the ethanol extract of the leaves of Ocimum gratissimum.
\end{abstract}

The ethanol leaf extract of the plant was obtained using cold maceration with ethanol and then filtered and concentrated using rotary evaporator. The extract was used for coagulant evaluations, pharmacognostic evaluation and chromatographic (thin layer chromatography) analysis. The LD50 was determined in rats using Lorkes method.

Microscopic result shows the presence of a covering or uniseratetrichomes, sclerenchyma none pitted with lumen and diacytic stomata. The numerical data obtained were $8.75 \%, 12 \%$ and $8.45 \%$ for moisture content, alcohol extractive value and total cash value. The LD50 shows that there was no death recoded because of the holistic use of the plants. The result of the coagulation research are as follow:

- Group 1 clotting time 1: 69 min and bleeding time 2:62min,

- group 2 clotting time 1: $39 \mathrm{~min}$ and bleeding time 4: 79min,

- group 3 clotting time 1: $37 \mathrm{~min}$ and bleeding time 1: 99min,

- group 4 clotting time $1: 81$ mins and bleeding time is $2: 28$ mins,

- group 5 clotting time is $1: 47 \mathrm{mins}$ and bleeding time is $2: 49 \mathrm{mins}$ )

This shows that the ethanol extract of Ocimum gratissimumon rats exhibited coagulant property. The phytochemical analysis of this plant reveals that it contains alkaloids, flavonoids, saponins, terpenoids, tannins, glycosides and resins.

It can therefore be concluded that the ethanol extract of Ocimum gratissimum possesses coagulant activity. This study can be of great importance to the development of new coagulant drugs.

Citation: Osualaet al.(2021) Pharmacognostic Evaluation and Coagulant screening of Ethanol Extract of the Leaves ofOcimumgratissimumL. (Lamiaceae) Journal

Keywords: Ocimum gratissimum; Labiatae; Coagulant; Phytomedicines

\footnotetext{
*Corresponding author: Felix N Osuala

Department of Pharmacognosy, Faculty of Pharmacy, Madonna University, Nigeria.

Copyright $(2022$ Author(s) retain the copyright of this article. This article is published under the terms of the Creative Commons Attribution Liscense 4.0 .
} 


\section{Introduction}

\subsection{Herbal Medicine}

Medicinal plants play an important role in the development of potent therapeutic agents. Herbs have been used by man since the beginning of human culture as a source of medicine, herbal medicine also referred to as botanical medicine, phytomedicine. Phytotherapy refers to treatment of ailments with herbs, herbal materials, herbal preparations and finished herbal products that contain active ingredient part of plants, or other plant materials, or combinations. Herbal medicine may also be defined as a preparation in which the main therapeutic activity depend on plant or fungal metabolite which contains and it is definite in terms of systems in which it is employed (Evans and Akam,1992)[1]. According to World Health Organization (WHO) herbal drugs are referred to as complete, labeled medicinal products that have vigorous ingredients, aerial or secretive parts of the plant or other plant material or combinations.

The use of plants as remedies for various ailments has formed the basis of our modern medicinal sciences According the World Health Organization (2008) [2] aroximately 80\% of Asia and Africa's population use traditional medicine as a form of healthcare for treatment of diseases including blood disorders. Plant extracts can be an alternative to currently used antiplatelet agents, as they constitute a rich source of bioactive chemicals. Compounds such as alkaloids, xanthones, coumarins, anthraquinones, flavonoids, stilbenes, and naphthalenes have been reported to have an effect on platelet aggregation. Chen et al., 2001 [3]. Furthermore, polyphenol-rich diets have been shown to be beneficial in vascular functioning including platelet aggregation in humans.

\subsection{Traditional use of herbal medicine}

In many developing countries, a large proportion of the population relies on traditional practitioners and their armamentarium of medicinal plants in order to meet healthcare needs. Although modern medicine may exist side-byside with such traditional practice, herbal medicines have often maintained their popularity for historical and cultural reasons. Such products have become more widely available commercially, especially in developed countries. In this modern setting, ingredients are sometimes marketed for uses that were never contemplated in the traditional healing systems from which they emerged. An example is the use of ephedra (Ma huang) for weight loss or athletic performance enhancement (Shaw, 1998) [4]. While in some countries herbal medicine are subject to rigorous manufacturing standards, this is not so everywhere. In Germany, for example, where herbal products are sold as 'phytomedicines', they are subject to the same criteria for efficacy, safety and quality as are other drug products. In the USA, by contrast, most herbal products in the market place are marketed amd regulated as dietary sulements, a product category that does not require pre-aroval of products on the basis of any of these criteria. Herbal medicine has its roots in every culture around the world, from the Greeks, to the Celts, the Romans to the Arabs, and the Chinese to the Indians to the Africans.

\subsection{Literature review}

\subsubsection{The family, Lamiaceae (Labiatae)}

The lamiaceae known as the Labiatae has around 3200 species and 200 genera (Lawrence, 1951) [5]. Despite being one of the larger families, the Lamiaceae is also one of the easier families to recognize, most of the time.

The Lamiacaeafamily is characterized by square stems, aromatic leaves and zygomorphic (irregular) flowers with the corolla usually 2-lied. It is a cosmopolitan family with many well-known members of horticultural and economic importance.

The Lamiacaea are mostly herbs or shrubs commonly with aromatic, herbage, quadrangular stems, and verticillate inflorescences. The leaves are oosite or whorled, gland-dotted and are simple or occasionally pinnately compound; stipules are absent.The leaves are often strongly aromatic due to ethereal oils located in the glandular hairs. The leaf blades are simple, rarely pinnately lobed or digitately compound with entire or toothed margins. The flowers are bisexual and zygomorphic. The calyx is synsepalous, typically 5-merous, sometimes 2-lied, and usually has 5-15 conspicuous ribs. The corolla is sympetalous and typically bilabiate with 2 lobes forming auer lip and 3 lobes forming a lower lip. The androecium consists of either 4 didynamousstamens or only two stamens that are adnate to the corolla tube or perigynous zone, alternate with the lobes. The gynoecium consists of a single compound ovary of 2 carpels, a single gynobasic style, and a deeply 4-lobed superior ovary with 4 aarentlocules (by intrusion of the ovary wall), each with a single basal-axile ovule. A hypogynous, often asymmetric nectariferous disk is generally present between the stamen and ovary. The fruit consists of four 1-seeded nutlets that are rarely maybe fleshy and drupaceous. There are lots of specialized pollination mechanisms in the lamiaceae. In some, the stamens are held within the bursts out of the 
anthers, all over the insect. In others, the pollinator pushes on a connective which effectively prevents access to the nectar; but in doing so, the other end of the stamina arm pivots and dumps pollen on the insects back.

The Lamiaceaeis global in distribution, with a particularly high concentration occurring in the Mediterranean region. In general, species of the Lamiaceae tend to grow in open habitats, and are often associated with a Mediterranean climate. Many of the species in the maquis vegetation of the Mediterranean belong to the Lamiaceae.

The smells associated with the Lamiaceae are from terpenes. Many of these compounds are effective in suressing the growth of other species. Some have been shown to suress the germination of grasses in the Carlifornian chaparral. Chemical warfare is normal among plants/

The Lamiaceae is an important family of plants. Many are cultivated as ornamentals (e.g Salvia, Coelus, and Ajuga), but others are important kitchen herbs, e.g .Ocimum (Basil), Origanum (Marjoram or Oreganum), Thymus, and Mentha. Lavendula (lavender) is grown for its oils.

The Lamiaceae belongs in Cronquist's Asteridae and is considered to be closely related to the Hydrophyllaceae, Boraginaceae, and Verbanaceae.

\subsubsection{Important medicinal plants from the family lamiaceae includes:}

- $\quad$ Melissa officinalis .L. (balm), a mild sedative, carminative and spamolytic.

- Lavender angustifolia miller (lavender), a mild carminative and spamolytic.

- Menthe arvenis .L. var. piperascensmalinvand (Japanese mint), yields a commonly used essential oil (for respiratory problems).

- $\quad$ Menthe spicata .L. (spear mint), a carminative and spasmolytic.

Menthe piperita .L. (peermint), a commonly used carminative and spasmolytic and a hybrid between M. spicata .L. and M. aquatic.L

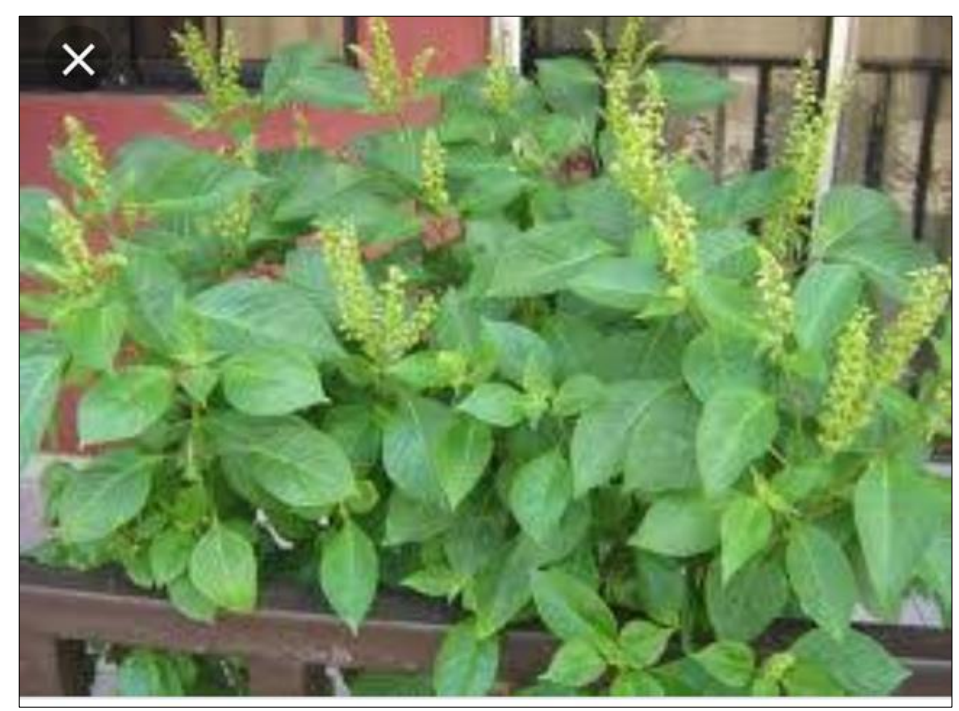

Figure 1 Ocimumgratissimumplant

\subsubsection{The genus, Ocimum}

The genusOcimum is ranked high among some of the astonishing herbs for having enormous medicinal potentials and the genus includes around 30 plant species from tropical and subtropical areas, which are much differentiated in respect of morphological and chemical features (Nurzynska-Wierdak 2001 [6], Vina and Murillo 2003 [7], Telci et al. 2006) [8].Ocimumis a genus of aromatic annual and perennial herbs and shrubs in the family of Lamiaceae, native to the tropical and warm temperate regions of all 6 inhabited continents, with the greatest number of species in Africa.

Ocimum unlike other economically important herbs in the Lamiaceae such as Rosmarinus, Thymus and Salvia, belongs in the tribe Ocimeae which has declinate stamens. That is the stamens lie over the lower lip of the corolla rather than 
ascending under the uer lip. The Ocimeae are essentially a tropical tribe and Ocimumoccurs naturally in tropical America, Africa and Asia. Unlike several other economic Lamiaceae, Ocimumrequires warmth for growth and should be protected from frost.

\subsection{Description of the species of Ocimumg ratissimum}

The use of plant materials as spices, condiments and for medical purposes dates back to the history of mankind (Garland, 1972 [9], Ogunyemi, 1979 [10]). Recently, the exploitation of wild plants for medicinal purposes has gained more acceptances in many countries of the world. To further underscore the importance of herbal medicine, most national governments have established the traditional medicine regulatory council under the supervision of their various health ministries to tap the numerous potentials of herbs, this is because traditioanal medicine has long been practiced even before orthodox medical practice aeared. Ocimum gratissimum belongs to the group of plants known as spices. The plant is an erect small plumb with many barnacles usually not more than $1 \mathrm{~m}$ high (Vierra and Simon, 2000) [11]. It is of the family Labiatae, genus Ocimum and species gratissimum (Iwu, 1993) [12]. In South East Asia, it is cultivated as a home garden crop but it is grown on a commercial scale in Vietnam. In Nigeria, it is Effinrin-nla in Yoruba, Daidoya in Hausa and Nchawu in Igbo. It is used in salads, soups, pastas, vinegars and jellies in many parts of the world. The Thai people are popularly known to use it in food flavoring. In traditional medicine, the leaves have been used as a general tonic and anti-diarrhea agent and for the conjunctivitis by instilling directly into the eyes; the leaf oil when mixed with alcohol is alied as a lotion for skin infections, and taken internally for bronchitis. The dried leaves are snuffed to alleviate headaches and fever among other uses (Iwu 1993) [12]. Although, conventional antibiotics have been very useful in orthodox medicine, it has been argued by many that its concomitant use with herbal extracts is not desirable as one normally antagonizes the activity of the other. Considering the fact that Ocimum gratissimumis used in most local dishes and foods to achieve a variety of purposes, there is need to ascertain if its extract antagonizes or acts as a synergy when used together with conventional antibiotics. In addition, despite the fact that the various extracts of Ocimum gratissimum have been tested in vitro and shown to be active against some bacterial and fungal isolates (Nakamura et al, 1999 [13], Nakamura et al, 2004 [14] and Silva et al, 2005) [15]

\subsubsection{Common names}

Wild basil, Ram tusil. African basil, Tree basil, Shrubby basil, Clove basil

\subsubsection{Scientific name}

Ocimum gratissimum

\subsubsection{Other names}

Nchawu in Igbo

Daidoya in Hausa

Effinrin-nla in Yoruba

Vridhutulsi in Sanskrit

Ram tusil in Hindi

Nimmatulasi in Kannada

Tchayo in fon(Benin)

Fobazen in Haiti

Kunudiri in Okirika

Yerba di hole in Papiamento

Ntonng in Ibibio 


\subsection{Pharmacognostic profile}

\subsubsection{Nomenclature and taxonomy of Ocimum gratissimum}

Kingdom: Plantae- Plants

Subkingdom: Tracheobionta-Vascular plants

Super division: Spermatophyta-Seed plants

Division: Magnoliophyta-Flowering plants

Class: Magnoliopsida-Dicotyladon

Subclass: Asteridae

Order: Lamiales

Family: Lamiaceae-Mint family

Genus: Ocimum L.

Species: gratissimum L.

\subsubsection{Morphology}

Ocimum gratissimumis a shrub up to $1.9 \mathrm{~m}$ in height with stems that are branched. The leaves measure up to $10 \times 5 \mathrm{~cm}$, and are ovate to ovate-lanceolate, sub-acuminate to acuminate at apex, cuneate and decurrent at base with a coarsely crenate, serrate margin, pubscent and dotted on both sides. The leaves show the presence of covering and glandular trichomes. Stomata are rare or absent on uer surface while they are present on the lower surface. Ordinary trichomes are few, while the long ones up to 6-celled are present on the margins mostly; the short ones which are 2 celled, are mostly found on the lamina. Petioles are up to $6 \mathrm{~cm}$ long and racemes up to 18co long. The peduncles are densely pubescent. Calyx is up to $5 \mathrm{~mm}$ long, campanulate and $5-7 \mathrm{~mm}$ long, greenish-yellow in colour. Nutlets are mucilaginous when they are wet.

\subsubsection{Chemical constituents}

Phytochemical evaluation of Ocimum gratissimum has shown that it is rich in alkaloids, saponins, tannins, phlobatannins, anthraquinones, steroids, terpenoids, flavonoids and cardiac glycosides (Akinmoladum et al;2007 [16] and Edeoga et al;2006) [17]. The fresh above ground parts of Ocimum gratissimum contain 0.8-1.2\% essential oil. The chemical composition of the oil is variable and at least 6 chemotypes have been reported, characterized by the main component of the essential oil: eugenol, citral, ethyl cinnamate, geraniol and linalool.

The plant is also said to contain major mineral elements like calcium, chloride, manganese, magnesium, zinc and potassium (Chen et al;1995) [3].

\subsubsection{Geographical distribution}

Ocimum gratissimum is found throughout the tropics and subtropics and its greatest variability occurs in tropical Africa and India. It is widely distributed throughout the Central America, West African coast and has been used in Trinidad and Tobago and in Nigeria for the treatment of various ailments (Bailey and Day, 1989 [18];Aguiyi et al, 2000 [19] ).

\subsubsection{Cultivation}

These plants are aromatic perennial herbs which go through several variations in cultivation to attain improved growth.

Growing conditions

Soil: This plant requires a well-drained soil like the delta regions.

Sunlight: It grows well in full exposure of sun. 
Climate: The summer temperatures are good for the plants. They grow in sea level lands as well as in altitudes of $1500 \mathrm{~m}$ above sea level.

Propagation: These herbs grow mostly on stem cuttings. Seedlings can be transplanted between February to March or from May to August. In stem cuttings procedure it usually takes 28 days for the plant to form roots. The tree produces for 5 to 10 years.

\subsection{Medicinal uses}

Ocimum gratissimum has been used extensively in the traditional system of medicine in many countries. In the NorthEast of Brazil, it is used for medicinal, condiments and culinary purpose. The flowers and the leaves of this plant are rich in essential oil, so it is used in the preparation of teas and infusions (Rabeloet al 1;2003) [20]. In the coastal areas of Nigeria, the plant is used in the treatment of epilepsy, high fever and diarrhea (Effrimet al 2003) [21]. In the savannah areas, decoctions of the leaves are used to treat mental illness (Akinmoladun et al, 2007) [16].Ocimum gratissimumis used by Ibos of South Eastern Nigeria in the management of the baby`s cord, to keep the wound surface sterile. It is also used in the treatment of fungal infections, cold and catarrh (Ijehet al, 2005) [22]. Brazilian tropical forest inhabitants used a decoction ofOcimumgratissimumroots as a sedative for children (Cristiana et al, 2006) [23]. People of Kenya and sub-Sahara Africa used it in the treatment of abdominal pains, sore eyes, infections, cough, barrenness, fever, convulsion and tooth gargle, regulation of menstruation and as a cure for the treatment of sunstroke, headache, and influenza, as a diaphoretic, antipyretic and for its anti-inflammatory activities (Oliver, 1960 [24];Tania et al, 2006) [25]

The tribes of Nigeria use the leaves extract in the treatment of diarrhea, while the cold leave infusions are used for the relief of stomach upset and haemorrhoids (Kabiret al l, 2005 [26]). The plant is commonly used in folk medicine to treat different disease such as uer respiratory tract infection, diarrhea, headache, disease of the eye, skin disease, pneumonia, cough, fever, and conjunctivitis (Adebolu and salau 2005 [27]). It is also used as a febrifuge, anti-malarial and anticonvulsant. The infusion of Ocimum gratissimum leaves is used as pulmonary antisepticum, anti-tussivum, antispasmodic (Ngassoumet al, 2003) [28].

\subsubsection{Alternative and complimentary medicinal uses}

Among the various species, Ocimum gratissimum finds extensive use clinically throughout the world. Formulations of the leaf essential oil of Ocimim gratissimum (Ocimum oil) have been incorporated in a variety of bases as topical antiseptics and for use in the treatment of minor wounds, boils and pimples (Orafidiya et al, 2005) [29]. Ijehet al (2005) [22] reported that Ocimum gratissimum and Xylopiathiopica in combination are used in the preparation of potions and teas for women during peuperium.

\subsection{Coagulation}

- Coagulation is a complex process by which blood forms clot. Coagulation is initiated almost instantly after an injury to the blood vessel which damages the endothelium (lining the vessel) (Giangranda, 2003) [30]

Over activity of the coagulation cascade (hypercoagulation) increases the risk of thromboses formation. This can easily lead to thromboembolisms which block blood flow and lead to ischemia with subsequent damage to the afflicted organs. Hereditary defects and habits, such as smoking, increase blood coagulability (Rang et al., 2007) [31]. On the other hand, anticoagulants (such as heparin and warfarin), antiplatelet drugs (aspirin) as well as fibrinolytics (streptokinase) decrease blood coagulation and the risk of thrombus formation (Vane \& Botting, 2003 [32];Rang et al., 2007) [31].

\subsubsection{Haemostasis}

Haemostasis is the body's normal physiological response for the prevention of bleeding/hemorrhage. It results in the blocking of the vascular breach, it helps generally to ensure blood fluidity and blood vessel integrity. It includes coagulation and antibody's Cardiovascular diseases remain a prominent killer today, including myocardial infarctions, strokes, and thromboses that can arise from pathologies associated with coagulation (Rang et al., 2007 [31];Buch et al., $2010[33])$.

\subsubsection{Relationship between coagulation and haemostasis}

Coagulation is an important part of haemostasis, which is one of the mechanism or stages of haemostasis. Duringthis process the fibrinogen is converted into fibrin. The fibrin threads get attracted to the loose platelet plug which blocks the ruptural part of the blood vessel and prevent blood loss completely (Guyton, 2006) [34]. 


\subsubsection{The complex process of coagulation}

The coagulation process is similar. However, it takes a few minutes for a blood clot to form. With such a chain reaction mechanism, there is always the risk of coagulation spreading from the site of the injury into the blood vessel and possibly involving the entire body, fortunately, this does not haen as the blood also contain substances that suress coagulation (so called inhibitors:e.gantithrombin, protein C and S) and keep the successful triggered coagulation process in check.

A thrombosis is a blood clot in a blood vessel which often blocks the flow in the entire vessel.

The development of the thrombosisis particularly promoted by large wound surfaces, such as regularly occur in the case of operations or large injuries, as these release pro-coagulatory substances (thromboplastin).

Thrombosis are also encouraged by slower blood flow, e.g through prolonged bed rest or rest sitting for many hours in an aeroplane, by atrial fibrillation or by arteriosclerosis changes in the walls of the blood vessels.

\subsubsection{Aim of study}

- pharmacognostic evaluation of the leaves of Ocimum gratissimum

- To investigate the phytochemical constituents present in the leaves of Ocimum gratissimum as claimed by herbal medicine

- To evaluate its coagulant effect on rats

\subsubsection{Significance of study}

Ocimum gratissimum leaf is screened for coagulant effect, treatment and control of bleeding. Its positive result can serve as a lead to production of drug remedies to blood bleeding

\section{Material and methods}

\subsection{Collection of Plant Material and Identification}

Fresh leaves of Ocimum gratissimum were collected from Madonna University botanical garden in Elele, Rivers state. The leaf sample was identified by the HOD pharmacognosy. Voucher specimen was deposited in the herbarium.

\subsection{Preparation of the Plant Material}

The collected leaves were air-dried to constant weight and further micronized using a roller mill (electric blender) into a coarse powder. This was stored in a closed container and used for pharmacognostic tests, chromatographic analysis and coagulation analysis.

\subsection{Materials}

\subsubsection{Solvent}

Ethanol and distilled water

\subsubsection{Reagent}

Dilute and Conc. $\mathrm{HCl}$, Dragend off reagent, Ferric chloride solution, Mayer's reagent, Fehlings solution, Ruthenium red solution, Phloroglucinol, Tetraoxosulphate (vi) acid (H2SO4), Pottasium hydroxide, Chloroform, Distilled water.

\subsubsection{Animal used}

Rats (weight range 86-109g)

\subsubsection{Standard drug}

Vitamin $\mathrm{K}$ 


\subsubsection{Aaratus}

Analytical balance (triple beam balance OHAUS), petri dishes, laboratory water bath (Genilab limited), conical flasks, stopwatch (venus), crucible, hot air oven (Gallenkamp, England model OV-335), Microscope (Supertex). Clean glass slide, con=ver slip, whatman filter paper No 1, cotton wool, indelible marker, syringes.

\subsection{Extraction Procedure}

Aroximately $600 \mathrm{~g}$ of the dry powdered plant material prepared was divided into two different $1000 \mathrm{ml}$ sterile flasks, with each of the sterile flask containing $300 \mathrm{~g}$ of the plant material which was soaked differently with $2500 \mathrm{ml}$ of ethanol at room temperature for 72 hours. The content was then filtered with a white handkerchief and was refiltered with Whatman N0. 1 filter paper and the filterate was gently evaporated to dryness and then packed in separate clean dry bottles and kept in the refrigerator until required.

\subsection{Macroscopic Examination of the Leaves}

The fresh leave sample was used for the description which was done under the following headingPetioles, Lamina, Composition, Venation, Margin, Apex, Base, Taste, Odour, Size ,Surface ,Outline ,Colour.

\subsection{Microscopic Evaluation of the Leaves}

This was carried out in order to study the anatomy of the leaf. The fresh sample from the various section of the leaf were used for the microscopic examination.

\subsection{Chemomicroscopy Test were carried for lignin, cellulose, hemicelluloses, suberin and cutin, calcium oxalate crystals, mucilage}

\subsection{Phytochemical Tests}

The preliminary analysis involves testing the presence or absence of the following plant constituent:alkaloids, saponins, glycosides, resins, flavonoids, tannins, oils, carbohydrate. (Trease and Evans, 1998) [35]

\subsection{Determination of Analytical Standards}

\subsubsection{Percentage Moisture Content}

A crucible plate was oven dried at the temperature of $40^{\circ} \mathrm{C}$ for about 15 minutes, cooled in a dessicator and weighed (W1), $2 \mathrm{~g}$ of the powdered drug ofOcimumgratissimum(W2) was weighed into the crucible plate and gently heated in the oven to a temperature of about $105^{\circ} \mathrm{C}$ for 6 hours at intervals of $3,2,1$ hours until a constant weight (W3) is obtained and cooling was done in a dessicator before reweighing.

$$
\% \text { MOISTURE }=\frac{\text { wt of sample in crucible }(\mathrm{W} 2)-\text { constant wt of sample in crucible }(\mathrm{W} 3)}{\text { wt of sample in crucible }(\mathrm{W} 2)-\text { wt of crucible }(\mathrm{W} 1)} \times 100
$$

\subsubsection{Determination of Extractive value}

Alcohol-soluble extractive value

Powdered Ocimum gratissimum(2g) was macerated with $100 \mathrm{ml}$ of ethanol (99-100\% BDH England) in a closed volumetric flask for 24 hours. The mixture was rapidly filtered into a clean dry beaker. $1 \mathrm{ml}$ of the filtrate was evaporated to dryness on water bath using an evaporating dish of known weight. It was further dried at $105^{\circ} \mathrm{C}$ for 6 hours. The dish was weighed after cooling in dessicators. The weight of the alcohol extractive value was obtained by subtracting the weight of the dish containing the dry alcohol extractive. The alcohol-soluble extractive value were calculated with reference to the air-dried powdered drug.

\subsubsection{Total Ash Value}

A porcelain crucible was placed in muffle furnace for 15 minutes at $30^{\circ} \mathrm{C}$, cooled in a dessicator for about one hour and the crucible was weighed (W1). $3 \mathrm{~g}$ of the sample is accurately weighed into the preheated porcelain crucible and reweighed (W2). The sample is ashed in a muffle furnace at $650^{\circ} \mathrm{C}$ for about 6 hours until the sample turns grey (white 
ash). The crucible is removed with tong, cooled in a dessicator and reweighed (W3). The percentage ash content is determined by the relationship;

$$
\% \text { Ash }=\frac{W 3-W 2}{W 2-W 1} \times 100
$$

\subsection{Chromatographic Analysis}

\subsubsection{Choosing a solvent system}

To ensure a good separation and identification of chemical constituents using chromatography, it is important that a good solvent system is chosen. The solvent system used should be one that carry along the spots as it moves upwards and it should not move with the solvent front. Methanol and Chloroform was used in a ratio of 1: 4 i.e $10 \mathrm{mls}$ of methanol and $40 \mathrm{mls}$ of chloroform.

\subsubsection{Thin Layer Chromatography}

Test Samples

- Methanol extract of Ocimum gratissimum

- $\quad$ Standard drug (Vitamin k)

\section{SOLVENT SYSTEM:Chloroform:Methanol4:1}

Materials: Percolated chromatographic plates, chromatographic tanks.

Thin layer plates of $20 / 10 \mathrm{~cm}$ coated with silica gel was used. The plate was first activated by heating in the laboratory oven at a temperature of 110 for 5 mins. The origin was marked atn $2 \mathrm{~cm}$ from the base of the plate while the solvent front was $10 \mathrm{~cm}$ from the origin. All the extracts and the standard drug were spotted at the baseline using a capillary tube. The plate was then inserted into the chromatography tank and allowed to develop until it got to the solvent front. The plate was removed and the solvent fronts marked and the plate was allowed to dry and viewed under UV light. The spots produced were marked, then the distance moved by the different spots were measured using a ruler and the values gotten were used to determine the Rf value. The Rf value was calculated using the formula;

$$
\mathrm{Rf}=\frac{\text { Distance moved byspot }}{\text { Distance moved by solvent }}
$$

\subsubsection{Acute toxicity study (LD50)}

The acute toxicity study of Ocimum gratissimum was evaluated using a total of 13 female rats, it was carried out using the method described by Dietrich Lorke, 1983 [36] Trease, G. E. and Evans, W. C. (2002) [37].

\subsubsection{Coagulant Analysis}

The coagulant activity of the ethanol extract of Ocimum gratissimum was evaluated using the standard method. A total of 15 rats were used. The animals were obtained from the animal house of Faculty of Pharmaceutical Sciences of Madonna University, Elele campus. They were grouped into 5 groups of 3 animals per group. The animals were treated as follows;

- $\quad$ Group1 with average weight of $0.106 \mathrm{~kg}$ received just feed and water.

- Group 2 with average weight of $0.095 \mathrm{~kg}$ received $75 \mathrm{mg} / \mathrm{kg}$ of clopidogrel orally.

- Group 3 with average weight of $0.082 \mathrm{~kg}$ received $10 \mathrm{mg} / \mathrm{kg}$ of vitamin $\mathrm{k}$ and $75 \mathrm{mg} / \mathrm{kg}$ of clopidogrel

- Group 4 with average weight of $0.1095 \mathrm{~kg}$ received $800 \mathrm{mg} / \mathrm{kg}$ of extract and $75 \mathrm{mg} / \mathrm{kg}$ of clopidogrel (high dose of extract)

- Group 5 with average weight of $0.106 \mathrm{~kg}$ received $400 \mathrm{mg}$ of the extract and $75 \mathrm{mg} / \mathrm{kg}$ of clopidogrel (low dose of extract)

After 5 consecutive days of administration of the drug and extract, the tail of the rats were marked with a tag aroximately $2 \mathrm{~mm}$ long and then cut at the mark. Then the tips of the tail was immersed in saline at $37^{\circ} \mathrm{C}$ and the time from cutting the tip of the tail to stoing the bleeding was recorded;this interval was defined as bleeding time and consecutively 
recorded, simultaneously the coagulation time was also recorded by placing some if the blood on a glass slide and the time it takes to clot was recorded.

\section{Results}

\subsection{Results for macroscopic description ofOcimumgratissim}

Table 1 Result of macroscopic analysis

\begin{tabular}{|l|l|}
\hline Character & Description \\
\hline Color & Green \\
\hline Condition & Fresh \\
\hline Venation & Reticulate \\
\hline Base & Wedged shaped \\
\hline Margin & Sinuate \\
\hline Petiole & Present \\
\hline Apex & Long \\
\hline Surface & Green, pubescent \\
\hline Outline & Sparsely hairy under surface and pitted gland \\
\hline Odour & Aromatic \\
\hline Taste & Characteristic \\
\hline
\end{tabular}

Table 2 Chemomicroscopy data for Ocimum gratissimum

\begin{tabular}{|c|c|c|}
\hline Test & Observation & Inference \\
\hline \multicolumn{3}{|l|}{ Lignin } \\
\hline $\begin{array}{l}\text { Powders + phloroglucino+ conc.HCl. observed } \\
\text { under microscope }\end{array}$ & Fibres were pink in color & Lignin present \\
\hline \multicolumn{3}{|l|}{ Starch } \\
\hline $\begin{array}{l}\text { Powders }+\mathrm{N} / 50 \text { iodine. Observed under } \\
\text { microscope }\end{array}$ & Blue-black color & Starch present \\
\hline \multicolumn{3}{|l|}{ Mucilage } \\
\hline Powders+ Ruthenium red & Pink color & Mucilage absent \\
\hline \multicolumn{3}{|l|}{ Calcium oxalate } \\
\hline Powders + conc. $\mathrm{HCl}$ & Disaearance of calcium oxalate & Calcium oxalate present \\
\hline \multicolumn{3}{|l|}{ Celluose } \\
\hline Powders + iodine $+80 \%$ sulphuric acid & Blue-black color & Cellulose present \\
\hline \multicolumn{3}{|l|}{ Cutin and suberin } \\
\hline $\begin{array}{l}\text { Powders }+ \text { chlorine +zinc iodine }+ \text { dilute } \\
\text { tincture of alkane }\end{array}$ & $\begin{array}{l}\text { Light yellow color and red stained } \\
\text { walls }\end{array}$ & Suberin and cutin absent \\
\hline \multicolumn{3}{|l|}{ Hemicellulose } \\
\hline Powder $+20 \%$ sodium Hydroxide & $\begin{array}{l}\text { Red coloration indicate presence } \\
\text { of hemicelluloses }\end{array}$ & Hemicelluloses present \\
\hline
\end{tabular}




\subsection{Results of phytochemical Test}

The various chemical tests carried out indicates the presence and absence of the following chemical groups.

Table 3 Results of the qualitative phytochemical tests carried out on the aqueous and ethanol extract ofOcimumgratissimum

\begin{tabular}{|c|c|c|}
\hline Tests & Observation & Inference \\
\hline \multicolumn{3}{|l|}{ Test for alkaloids } \\
\hline Mayer's reagent & Milky precipitate was observed & Alkaloids present \\
\hline Dragendoff's reagent & Brick red colouration & Alkaloids present \\
\hline Wagner's reagent & Reddish brown colouration observed & Alkaloids present \\
\hline Picric acid & Yellow precipitate was observed & Alkaloids present \\
\hline \multicolumn{3}{|l|}{ Test for flavonoids } \\
\hline Ammonium test & Yellow coloration confirms the presence of flavonoids & Flavonoids present \\
\hline \multicolumn{3}{|l|}{ Tests for glycosides } \\
\hline Fehling's test & Brick red precipitate confirms the presence of flavonoids & Reducing sugar present \\
\hline \multicolumn{3}{|l|}{ Test for saponin } \\
\hline Frothing test & A stable foam upon standing indicates presence of saponin & Saponin present \\
\hline \multicolumn{3}{|l|}{ Test for terpenoids } \\
\hline & A grey colour indicates the presence of terpenoids & Terpenoids present \\
\hline \multicolumn{3}{|l|}{ Test for tannins } \\
\hline Ferric chloride test & Greenish black colour indicates presence of tannins & Tannins present \\
\hline \multicolumn{3}{|l|}{ Test for resins } \\
\hline & Precipitate occurring indicates the presence of resins & Resins present \\
\hline
\end{tabular}

\subsection{Results of the Determination of Analytical Standards}

Table 4 Results of the Analytical Standards

\begin{tabular}{|l|l|}
\hline Parameter & $\mathbf{\%}(\mathbf{w} / \mathbf{w})$ \\
\hline Moisture content & 8.75 \\
\hline Alcohol extractive value & 12 \\
\hline Total cash value & 8.45 \\
\hline
\end{tabular}

\subsection{Results of Percentage Yield}

Percentage yield $=7.6 \%$

\subsection{Results of chromatography}

Table 5 Results of thin layer chromatography

\begin{tabular}{|l|c|c|c|c|c|}
\hline Samples & Number of spots & Distance moved by spots & Solvent front & Rf values & hRf (\%) \\
\hline Extract & 1 & 6.6 & $10 \mathrm{~cm}$ & 0.66 & 66 \\
\hline Vitamin K & 1 & 4.4 & $10 \mathrm{~cm}$ & 0.44 & 44 \\
\hline
\end{tabular}




\subsection{Result of acute toxicity test}

Table 6 Result of the Acute Toxicity Test of ethanol extract ofOcimumgratissimum

\begin{tabular}{|l|l|c|}
\hline Stages & Dose & No of death \\
\hline Stage 1 & $10 \mathrm{mg} / \mathrm{kg}$ & $0 / 3$ \\
\cline { 2 - 3 } & $100 \mathrm{mg} / \mathrm{kg}$ & $0 / 3$ \\
\cline { 2 - 3 } & $1000 \mathrm{mg} / \mathrm{kg}$ & $0 / 3$ \\
\hline Stage 2 & $1600 \mathrm{mg} / \mathrm{kg}$ & $0 / 1$ \\
\cline { 2 - 3 } & $2900 \mathrm{mg} / \mathrm{kg}$ & $0 / 1$ \\
\cline { 2 - 3 } & $5000 \mathrm{mg} / \mathrm{kg}$ & $0 / 1$ \\
\hline
\end{tabular}

The extract was well tolerated at doses up to $5000 \mathrm{mg} / \mathrm{kg}$ body weight in rats

\subsection{Results of Coagulation Analysis}

Table 7 Result for Coagulation Analysis

\begin{tabular}{|c|c|c|c|}
\hline GROUPS & DOSE AND TREATMENT & CLOTTING TIME (min) & BLEEDING TIME (min) \\
\hline \multirow[t]{3}{*}{ GROUP 1} & \multirow{3}{*}{$\begin{array}{l}\text { No administered drug } \\
\text { (Control) }\end{array}$} & 2: 00 & 4:09 \\
\hline & & 1: 06 & $2: 30$ \\
\hline & & 2: 00 & $1: 47$ \\
\hline \multirow[t]{3}{*}{ GROUP 2} & \multirow[t]{3}{*}{$75 \mathrm{mg} / \mathrm{kg}$ of Clopidogrel only } & 1: 50 & $3: 34$ \\
\hline & & 1: 33 & 6:04 \\
\hline & & $1: 35$ & 5: 00 \\
\hline \multirow[t]{3}{*}{ GROUP 3} & \multirow{3}{*}{$\begin{array}{l}75 \mathrm{mg} / \mathrm{kg} \text { of Clopidogrel and } \\
10 \mathrm{mg} / \mathrm{kg} \text { of Vit } \mathrm{K}\end{array}$} & $1: 52$ & $1: 35$ \\
\hline & & $1: 21$ & $2: 36$ \\
\hline & & $1: 37$ & $2: 25$ \\
\hline \multirow[t]{3}{*}{ GROUP 4} & \multirow{3}{*}{$\begin{array}{l}75 \mathrm{mg} / \mathrm{kg} \text { of Clopidogrel and } \\
800 \mathrm{mg} / \mathrm{kg} \text { of extract (high } \\
\text { dose) }\end{array}$} & $1: 55$ & $2: 38$ \\
\hline & & 2: 51 & 1:09 \\
\hline & & $1: 38$ & $3: 38$ \\
\hline \multirow[t]{3}{*}{ GROUP 5} & \multirow{3}{*}{$\begin{array}{l}75 \mathrm{mg} / \mathrm{kg} \text { of Clopidogrel and } \\
400 \mathrm{mg} / \mathrm{kg} \text { of extract } \\
\text { (low dose) }\end{array}$} & 1: 47 & $3: 27$ \\
\hline & & 1: 49 & $2: 21$ \\
\hline & & 1: 45 & $2: 00$ \\
\hline
\end{tabular}

Table 8 Mean number of Clotting time and bleeding time

\begin{tabular}{|l|l|c|c|}
\hline GROUPS & DOSE AND TREATMENT & CLOTTING TIME (min) & $\begin{array}{l}\text { BLEEDING } \\
\text { TIME(min) }\end{array}$ \\
\hline Group 1 & No drug admistered & $1: 69$ & $2: 62$ \\
\hline Group 2 & $75 \mathrm{mg} / \mathrm{kg}$ of Clopidogrel only & $1: 39$ & $4: 79$ \\
\hline Group 3 & $75 \mathrm{mg} / \mathrm{kg}$ of Clopidogrel and 10mg/kg of Vit K & $1: 37$ & $1: 99$ \\
\hline Group 4 & $\begin{array}{l}75 \mathrm{mg} / \mathrm{kg} \text { of Clopidogrel and } 800 \mathrm{mg} / \mathrm{kg} \text { of extract } \\
\text { (high dose) }\end{array}$ & $1: 81$ & $2: 28$ \\
\hline Group 5 & $\begin{array}{l}75 \mathrm{mg} / \mathrm{kg} \text { of Clopidogrel and } 400 \mathrm{mg} / \mathrm{kg} \text { of extract } \\
\text { (low dose) }\end{array}$ & $1: 47$ & $2: 49$ \\
\hline
\end{tabular}

\section{Discussion}

The morphological description of the leaves from the collected sample was found to be identical with that described by (Trease and Evans, 2002) [37]. 
The leaf has the following cell wall components:lignin, cellulose, hemicelluloses and starch, mucilage, suberin and cutin were absent. Microscopical examination reveals the presence of covering trichomes and elongated epidermal cells with straight and wavy identical anticlinial walls. These parameters are valuable in the identification and detection of adulterant.

Preliminary phytochemical screening of the plantOcimumgratissimum, revealed the presence of several biological substances such as alkaloids, tannins, cardiac glycosides and so on, this is suorted by findings in Afolabi et al;2007 [38]. The presence of these secondary metabolites in this plant can be used as remedy for antimicrobial, antiemetic, and wound healing and so on. Tannins has astringent properties, hasten the healing of wound and antidote for healing of wound and antidote in the treatment of alkaloidal poisoning (Luis et al;2004) [39]. The study of saponin has illustrated the beneficial effects on blood cholesterol level, cancer, bone health and stimulation of the immune system. The nonsugar parts of saponins also have direct antioxidant activity and studies on antioxidants has shown its ability to attenuate nausea and vomiting. Different alkaloids have different medical benefits ranging from antihypertensive, antidiabetic and so on.

Ash constitutes the inorganic residues obtained after complete combustion of crude drugs, thus ash value is a validity parameter used to assess the purity of a given drug (Kokateet al, 2006) [40]. The proximate analysis obtained comply with the pharmacopoeia standard. The proximate and qualitative analysis result shows that the powdered leaf moisture content is $8.75 \%$ which shows that the powdered leaves will not be readily acted upon by microorganism, free from debris or dirt because of the low level of the total cash value $8.45 \%$ thereby showing that the leaves were properly collected and dried before extraction.Extractive values are representative of the presence of the polar or non-polar extractive compounds in the plant material. In the chromatographic analysis, plant extract and the standard drug where spotted on the TLC plate.

Acute toxicity test was carried out and there were no death recorded in the animals. Coagulation activities of the ethanol extract of Ocimum gratissimum were reported, the plant (leaf) extract caused coagulation of blood and also decrease the bleeding time when compared to the coagulant agent (vitamin $\mathrm{k}$ ) a standard drug which caused a short bleeding time and short coagulation time. The coagulation analysis of Ocimum gratissimum is not dose dependant.

\section{Appendix}

\subsection{Appendix 1}

Calculation for percentage yield

Weight of powdered Ocimum gratissimum $=600 \mathrm{~g}$

Weight of extract $=45.6 \mathrm{~g}$

Percentage yield $=\frac{\text { Weight of extract }}{\text { Total weight of dry sample }} \times 100$

$\%$ Yield $=\frac{45.6}{600} \times 100$

$=7.6 \%$

\subsection{Appendix 2}

Calculation of percentage moisture content

Weight of powder $(\mathrm{W} 1)=2 \mathrm{~g}$

Weight of crucible $=32.765 \mathrm{~g}$

Weight of crucible + powder $(\mathrm{W} 2)=34.765 \mathrm{~g}$

After heating weight of crucible + powder (W3) $=34.59 \mathrm{~g}$ 
$\%$ Moisture content $=\frac{\mathrm{W} 2-\mathrm{W} 3}{\mathrm{~W} 1} \times 100$

$=\frac{34.765-34.59}{2} \times 100$

$=8.75 \%$

\subsection{Appendix 3}

Calculation of alcohol extractive value

Powdered drug= $2 \mathrm{~g}$

Alcohol (ethanol) $=100 \mathrm{ml}$

Initial volume after filtration $=80 \mathrm{ml}$

Volume of extract used $=2 \mathrm{ml}$

Weight of empty crucible $=41.010 \mathrm{~g}$

Weight of crucible + extract after drying $\left(105^{\circ} \mathrm{C}\right)=41.026 \mathrm{~g}$

Weight of dry extract $=41.016-41.010=0.006 \mathrm{~g}$

Wt of dry Ext $=\frac{0.006 \mathrm{~g} \times 80 \mathrm{ml}}{2 \mathrm{~g}}$

$\% \frac{0.006 \mathrm{~g} \times 80 \mathrm{ml}}{2 \mathrm{~g}} \times 100=24 \%$

\subsection{Appendix 4}

Calculation of total cash value

Weight of crucible $A=32.788 \mathrm{~g}$

Weight of crucible + powder B $=34.788 \mathrm{~g}$

Weight of powder $\mathrm{C}=\mathrm{A}-\mathrm{B}=2.00 \mathrm{~g}$

Weight of crucible + Ash (D) $=32.957 \mathrm{~g}$

Weight of ash $=\mathrm{D}-\mathrm{A}=0.169 \mathrm{~g}$

$\%$ Ash value $\frac{0.169 \mathrm{~g}}{2 \mathrm{~g}} \times 100=8.45 \%$

\subsection{Appendix 5}

Calculation of Rf value

$\mathrm{Rf}=\frac{\text { distance moved by solute }}{\text { distance moved by solvent }}$

For ethanol Extract ofOcimumgratissimum $=\frac{6.6}{10}=0.66$

For Vitamin $\mathrm{K}=\frac{4.4}{10}=0.44$

Calculation of hRf value 
$h \operatorname{Rf}=\operatorname{Rf} \times 100$

For ethanol extract ofOcimumgratissimum $=0.66 \times 10=66$

For Vitamin $\mathrm{K}=0.44 \times 100=44$

\section{Conclusion}

According to the results obtained the coagulant analysis of the ethanol leaf extract of Ocimum gratissimum showed that the leaf possesses coagulation properties as is seen from the experiment. The extract caused coagulation and decreased bleeding time at almost same level with the standard drug Vitamin $\mathrm{k}$ and its coagulant effect is not dose dependent. The leaves are considered safe. The results of this study could be of great importance therefore it is recommended that more tests on the coagulant activity of this plant be carried out.

\section{Compliance with ethical standards}

\section{Acknowledgments}

I acknowledge Laboratory Technologists in Pharmacognosy Department, faculty of pharmacy, Madonna University Nigeria,

\section{Disclosure of conflict of interest}

There is no conflict of interest among the authors

\section{References}

[1] Evan EG, Akam UJ Enem. A text on herbal medicine, orient paper backs. 1992; 1:512-515.

[2] World Health Organization. "Traditional Medicine Definitions". 2008-2012.

[3] Chen MD, Lin PY, Tsou CT, Wang JJ, Lin WH. Selected Metal Status in Patient with non-insulin dependent diabetes Mellitus. Biology of Trace Element Research. 1995; 50(2): 119-124.

[4] Shaw D. Risks or remedies? Safety aspects of herbal remedies. J. Roy. Med. 1998; 91: 294-296.

[5] Lawrence HM. Taxonomy of Vascular Plants. New York:Macmillan. 1951; 823.

[6] Nurzynska-Wierdak R. Analizazawartosci I skladuchemicznegoolejkudwoch form bazyliiwonnej (Ocimum gratissimumL.). Ann. UMCS, EEE, IX sul. 2001; 189-193.

[7] Vina A, Murillo E. Essential oil composition from twelve varieties of basil (Ocimum s) grown in Colombia. J. Braz. Chem. Soc. 2003; 14(5): 744-749.

[8] Telci I, Bayram E, Yilmaz G, Avci B. Variability in essential oil composition of Turkish basils (Ocimum basilicum L.). Biochem. Syst. Ecol. 2006; 34: 489-497.

[9] Garland S. The Herbs and Spices book. Frances Lincoln Publication. London. 1972; 20-27.

[10] Ogunyemi MA. The origin of the herbal cure and its spread. University of Ife Press, Ileife. 1979; 20-22.

[11] Vierra RF, Simon JE. Chemical characterization of Ocimum gratissimum found in the market and used in Traditional medicine in Brazil. Journal of Economics Botany. 2000; 20: 5-6.

[12] Iwu MM .Handbook of African medicinal plants, CRC Press Inc. Boca Raton, Floridamm. 1993.

[13] Nakamura CV,Nakamura TU,Bando E,Melo AFN,Cortez DAG,Dias Filho BP. Antibacterial activity ofOcimumgratissimumL. essential oil.Mem.Inst. Oswaldo Cruz. 1999; 94: 675-78.

[14] Nakamura CV, Ishid K, Faccin LC, Filho BP, Cortez DA, Rozental S, Souza W, Ueda N. In vitro activities of essential oils from Ocimum gratissimum against four candida species. Research in Microbiology. 2004; 155(7): 579-86.

[15] Silva MRM, Oliveira JG Jr, Fernades OFL, Passos XS, Costa CR, Souza LRH, Lemos JA, Paula JR.Antifungal activities ofOcimumgratissimumtowards dermatophytes; J. Ethnopharmacol. 2005; 48(1): 72-86. 
[16] Akinmoladun AC, Ibukun EO, Afor E, Obuotor EM, Farombi EO. Phytochemical constituents and antioxidant activity of extracts from the leaves of Ocimum gratissimum. Sci. Res. Essay. 2007; 2: 63-166.

[17] Edeoga HO, Omosun G, Uche LC. Chemical composition of Hyptissuaveolens and Ocimum gratissimum hybrids from Nigeria. Afr. J. Biotechnol. 2006; 5: 892-895.

[18] Bailey CJ, Day C. Traditional plants medicine as treatment for diabetes .Diabetes care. 1989; 12: 553-564.

[19] Aguiyi, JC, Obi CI, Gyang SS .Hypoglycaemic activity of Ocimum gratissimumin rats. Fitoterapia. 2000; 71(4): 44460.

[20] Rabelo M,Souza EP, Soares PMG. Antinociceptive properties of essential oil of Ocimim gratissimum L. in mice. Braz J Med Biol Res. 2003; 36: 521-524.

[21] Effrim KD, Jacks TW, Sodipo OA. Histopathological studies on the toxicity of Ocimum gratissimum leave extract on some organs of rabbit. African journal Biomed Res. 2003; 6: 21.

[22] Ijeh II, Omodamiro OD, Nwanna IJ. Antimicrobial effects of aqueous and ethanolic fractions of two spices, Ocimum gratissimum and Xylopiaaethiopica. African Journal Biotech. 2005; 4: 953-56.

[23] Cristiana M, Murbach F, M'arcia OM, Mirtes C. Effects of seasonal variation on the central nervous system activity ofOcimumgratissimum(L) essential oil. J Ethnopharmacol. 2006; 105: 161-66.

[24] Oliver B.Medicinal plants in Nigeria. University of Ibadan. 1960; 358.

[25] Tania Ueda, Nakamura RR, Mendonca F. Antileishmanial activity of Eugenol-rich essential oil fromOcimumgratissimumParasitol int. 2006; 55: 99-105.

[26] Kabir OA, Olukayode O, Chidi EO, Christopher CI, Kehinde AF. Screening of crude extracts of six medicinal plants used in South-West Nigerian unorthodox medicine for anti-methicillin resistant Staphylococcus aureus activity. BMC Complement Altern Med. 2005; 5: 1-7.

[27] Adebolu TT, Salau AO. Antimicrobial activity of leaf extracts of Ocimum gratissimumon selected diarrhea causing bacteria in south western Nigeria. Afr J Biotech. 2005; 4: 682-84.

[28] Ngassoum MB, Jessia-Ngang JJ, Tastsadjieu L.N, Jirovetz L, Buchbauer G, Adjoudji O. Antimicrobial study of essential oils of Ocimum gratissimum leaves and Zanthoxylum xanthoxyloids fruits from Cameroon. Filoterapia. 2003; 74:284-87.

[29] Ngassoum MB, Jessia-Ngang JJ, Tastsadjieu LN, Jirovetz L, Buchbauer G, Adjoudji O. Antimicrobial study of essential oils of Ocimum gratissimum leaves and Zanthoxylum xanthoxyloids fruits from Cameroon. Filoterapia. 2003; 74: 284-87.

[30] Giangranda PL. "Six character in search of an author: The history of the nomenclature of coagulation factors" British journal .Haematol. 2003; 121(5): 703-12.

[31] Rang HP, Dale MM, Ritter JM, Flower RJ. Haemostasis and thrombosis. In:Rang and Dale's Pharmacology 6th edition. Churchill Livingstone (Elsevier). 2007; 332-345.

[32] Vane JR, Botting RM. "The mechanism of action of aspirin". 2003-06-15.

[33] Buch MH, Prendergast BD, Storey RF. Antiplatelet therapy and vascular disease:An update. Ther Adv Cardiovasc Dis. 2010; 4: 249-275.

[34] Guyton AC. Textbook of Medical Physiology, 11 Ed, W.B Saunders company Philadelphia. 2006; 894-897.

[35] Trease GE,Evans WC.Trease and Evans Pharmacognosy. 15th edition, W. R. Saunders, London. 2002.

[36] Lorke D. A new aroach to practical acute toxicity testing. Arch. Toxicol. 1983; 53: 275-279.

[37] Trease GE, Evans WC.Trease and Evans Pharmacognosy. 15th edition, W. R. Saunders, London. 2002.

[38] Afolabi C,Akinmoladun EO, Ibukun EA ,Obuotor EM, Farombi EO. Phytochemical constituents and antioxidant activity of extracts from the leaves of O. gratissimum, Scientific Research and Essay. 2007; 2(5): 163-166.

[39] Luis W, Jiang SB, Wus G. Tannin inhibit HIV-2 entry by targeting gp41, Actapharmacosin. Feb 2004; 25(2): 213-8

[40] Kakote CK, Purohit AP, Gokhale SB.Text Book of Pharmacognosy. 2006; 109-133. 